\title{
CO-OWNERSHIP OF MATRIMONIAL PROPERTY: RADICAL PROPOSALS FOR REFORM
}

\author{
Lorna Fox, Lecturer in Law, Queen's University Belfast*
}

\section{INTRODUCTION}

In December 2000, the Law Reform Advisory Committee for Northern Ireland (the LRAC) issued its Final Report on Matrimonial Property. ${ }^{1}$ This paper proposed a scheme of radical and far-reaching reform in respect of the law governing the ownership of the family home, and of household goods and housekeeping money, between spouses and cohabitants. The LRAC's Final Report recommended that, in respect of the joint residence of spouses or 'qualifying cohabitants',

Where one transfers property to the other, or one transfers property to both, or where one purchases property or both purchase property, the beneficial ownership of that property will vest in both spouses or cohabitants as joint tenants unless the parties agree otherwise expressly in writing. ${ }^{3}$

Similar proposals were lodged in respect of housekeeping money and household goods. ${ }^{4}$ Although the concept of statutory co-ownership of matrimonial property has been raised as a possible policy alternative in England and Wales and in the Republic of Ireland, initiatives to introduce

* I would like to thank the Editor and the anonymous referee, both of whom made helpful comments on an earlier draft. I am also grateful to Judith Fox, who discussed with me some of the issues considered in this article. All property in errors remains with the author.

1 Matrimonial Property, Law Reform Advisory Committee Report No 10, (LRAC No 8, 2000), hereafter 'Final Report'. This report followed, and should be read in conjunction with, the Committee's 1999 Discussion Paper on the subject, Discussion Paper No 5, Law Reform Advisory Committee for Northern Ireland, (1999), hereafter 'The Discussion Paper'.

2 The Final Report defined 'qualifying cohabitants' as partners who: “. . . (i) have been living together in the same household for at least a total of two years within the period of the three years preceding the property transaction effectively as husband and wife though not being married; or (ii) have had a child by the relationship and have been living together in the same household effectively as husband and wife though without being married."; Chapter 6, Recommendation 3. Although the Recommendations include property acquired by parties prior to becoming spouses whenever such property was acquired or transferred in contemplation of marriage for the purposes of their principal joint residence (Recommendation 2), the provisions only extend in the case of 'qualifying cohabitants' to include property acquired after the cohabitants have become qualifying cohabitants.

3 See Final Report, Recommendations 1 and 3.

4 Money transferred from one spouse to another, or used to buy property for common purposes would be jointly owned subject to a contrary intention on the part of either spouse, made known to the other spouse at the time of acquisition or transfer; see Final Report, Chapter 3 and Recommendations 4-7, also Discussion Paper, paras $6.8-6.9,6.12-6.13$. This article will focus on the implications of the proposals in respect of the joint residence. 
statutory co-ownership between spouses in these jurisdictions have run aground. The Northern Ireland proposals, if enacted, would therefore represent a significant policy departure.

These Recommendations, if enacted, would not only have serious implications for the ownership of matrimonial assets, real and personal, between spouses and 'qualifying cohabitants', but would also affect dealings with third party creditors or purchasers concerning such property. This article considers the proposals of the LRAC, and the policy which its recommendations endeavour to promote. The comparison drawn by the Committee $^{5}$ between Northern Ireland and other Commonwealth jurisdictions will also be reviewed. This will be followed by analysis of comparable legislative initiatives in England and Wales and in Ireland, and the reasons for the rejection of these initiatives. Finally, the implications of the proposed Northern Ireland reforms will be assessed, in terms of both the ownership of matrimonial property between the partners themselves, and in respect of their dealings with third parties.

\section{MATRIMONIAL PROPERTY - THE NORTHERN IRELAND PROPOSALS}

The LRAC has recommended that:

". . . in the case of a joint residence (or if the parties have more than one residence in the case of their primary residence) where the spouses are living together and:

one spouse transfers the property to the other;

one spouse transfers the property to both spouses jointly;

one spouse purchases the property; or

both spouses jointly purchase the property

the spouses should be entitled as joint tenants in equity to the beneficial interest in the property unless the parties agree otherwise in writing." 6

This principle is extended to include property acquired or transferred prior to the parties becoming spouses where the property is acquired or transferred in contemplation of marriage for the purposes of their principal joint residence. ${ }^{7}$ The Report has also recommended that the same principle apply to 'qualifying cohabitants', so long as they are living together, and the property is acquired after the cohabitants become qualifying cohabitants. ${ }^{8}$ Although based on proposals made in respect of statutory co-ownership of matrimonial assets by the English Law Commission in $1988,{ }^{9}$ the Northern Ireland Report goes much further than the antecedent English recommendations.

The Northern Ireland proposals are more radical than those recommended (but not yet adopted) in England and Wales, in two main respects. First, the

5 See Discussion Paper, Chapter 4.

6 Final Report, Recommendation 1.

7 Final Report, Recommendation 2.

8 See Final Report, Recommendation 3.

9 Family Law: Matrimonial Property, Law Com No 175 (1988). 
Northern Ireland proposals purport to affect not only property ownership between spouses, but also between 'qualifying cohabitants'. 'Qualifying cohabitants' are defined in the Final Report as parties who:

"(a) have been living together in the same household for at least a total of two years within the period of the three years preceding the property transaction effectively as husband and wife though not married; or

(b) have had a child by the relationship and have been living together in the same household effectively as husband and wife though without being married."

Furthermore, whilst the English Law Commission confined its recommendations to housekeeping money and household goods, ${ }^{10}$ the Northern Ireland proposals encompass both the personal property of spouses and qualifying cohabitants, and their 'joint residence'.

These proposals would clearly have a significant impact on both the ownership of property as between the partners, ${ }^{11}$ and with regard to external dealings which concern matrimonial property and third party purchasers or creditors. This section therefore begins by considering the reasoning of the LRAC, and the arguments which the Committee has proffered in support of its proposals for the reform of matrimonial property.

\section{(a) The reasoning of the LRAC: deficiencies of the present position}

When introducing the proposed reforms, the LRAC clearly identified the mischief at which the initiative was directed. The Committee expressed concern about the lack of legislative provision for the 'special needs' of spouses and cohabitants, and the fact that:

"[t]he ownership of the family home in Northern Ireland is governed by essentially the same principles as apply to the ownership of any other real property." 12

It was noted that while the court has power to re-distribute assets between spouses in divorce, nullity and judicial separation proceedings, ${ }^{13}$ there is no judicial discretion to re-allocate property interests in respect of non-legal title holding cohabitants in the event of separation. ${ }^{14}$ The LRAC was also

10 See Law Com No 175 (1988), para 4.3.

11 The term 'partners' will henceforth be used to refer to spouses and 'qualifying cohabitants'.

12 Final Report, para 2.1. See also Discussion Paper, para 3.1. "The legal ownership of land is determined by the names on the title deeds, in the case of unregistered land, and by the names appearing on the folio in the case of registered land. The beneficial ownership of land is determined in accordance with the principles of equity"; ibid.

13 Matrimonial Causes (NI) Order 1978. See Final Report, para 2.7; Discussion Paper, para 3.7.

14 "The adjustative powers of the Court in divorce and related proceedings under the Matrimonial Causes (NI) Order 1978 enable the Court to achieve a balanced and just result between the spouses in the event of the marriage being terminated. No such powers are available to the Court as between cohabitants. Thus in a 
concerned about the property implications following the death of one partner when the family home is not co-owned, since Northern Ireland law does not presently provide that property should necessarily pass to the surviving partner on death. ${ }^{15}$ Finally, while non-owning spouses were given a statutory right of occupation against their partner by the Family Law (Miscellaneous Provisions) (NI) Order 1984, ${ }^{16}$ extended by the Family Homes and Domestic Violence (NI) Order 1998 to include cohabitants, the 'matrimonial home rights' conferred under this order are only effective against third parties if registered, and only spouses are entitled to register matrimonial home rights. ${ }^{17}$ The Committee concluded that, for both spouses and cohabitants: ". . . there remain areas of potential injustice." 18 It was suggested that the nature of property in the family home and other matrimonial assets justified the development of a special set of rules to govern its ownership; that: ". . . the home of a couple in a particular type of relationship. . ."19 ought to be accorded a special status over other types of property. ${ }^{20}$

The Committee proceeded by considering the equitable principles which, in the absence of specific statutory provisions, currently govern the acquisition of ownership interests in matrimonial (and other) property. Since the decision of the Northern Ireland Court of Appeal in McFarlane $\mathrm{v}$ McFarlane ${ }^{21}$ it has been firmly established that a non-legal title holder can only acquire an equitable interest in property ${ }^{22}$ where he or she has made a direct contribution to the purchase price of that property, or where there has been some 'agreement, arrangement or understanding' that he or she would acquire an ownership interest, supported by 'detriment' in the form of direct or indirect contributions. The net result has been that, in the absence of some 'agreement, arrangement or understanding', non-financial contributions, such as those which might be made by a spouse or cohabitant in respect of caring for children of the relationship, or labour in the home, are not taken into

breakdown in their relationship the parties' rights would be determined in accordance with the ordinary proprietary interests. .."; Discussion Paper, para 4.3.

15 "There exists no presumption that the family home is jointly owned by the husband and wife, let alone that such ownership is equal and that the home should devolve automatically to the survivor"; Discussion Paper, Preface, $p$ iv; see also Preface to Final Report.

16 The provisions of the Family Law (Miscellaneous Provisions) Order 1984 provided that a 'non-owning spouse' who had registered a right of occupation could retain occupation of the home against a purchaser from or creditor of the owning spouse.

17 Family Homes and Domestic Violence (NI) Order 1998, Articles 5 and 6.

18 Discussion Paper, Preface, $p$ iv. The Committee added that: "One such area would be where a marriage has not broken down, but a third party, such as a creditor, seeks to enforce rights against the family home. In such circumstances the wife would require to establish an interest in accordance with the law as it now stands, otherwise her home and that of the entire family would be vulnerable"; ibid.

19 See Preface, Final Report.

20 The Committee added that: "There is also the argument that the nature of the property which is being considered - the family home and its contents - requires its ownership to be placed on a settled and equitable basis which is clear and known to all parties from the outset"; Discussion Paper, Preface, p iv.

21 [1972]NI 59. This NI decision was endorsed by the House of Lords in Lloyd's Bank v Rosset [1991]1 AC 107.

22 Under a resulting or a constructive trust. 
account by the court when assessing whether a beneficial interest has been acquired by a non-title holder. ${ }^{23}$ Even where the non-legal title holder has made indirect financial contributions, for example, paying household bills, thereby enabling the legal title holder to apply his or her assets towards mortgage payments, ${ }^{24}$ recognition of an interest in the property has depended upon proof of an 'agreement, arrangement or understanding'. In the context of personal relationships, evidence of such agreement can often prove elusive. ${ }^{25}$

The Committee asserted that the existing law in relation to the acquisition of ownership interests in the matrimonial home: “. . produces an unsatisfactory and unconvincing result." 26 Aside from the general observation that " $\mathrm{t}] \mathrm{he}$ decisions [in McFarlane v McFarlane and Lloyd's Bank plc v Rosset] are premised on the proposition that the question of beneficial ownership between spouses should be determined on the same basis as if they were strangers.";27 the Committee was concerned about the specific difficulties which this need for direct contributions or evidence of agreement presents in relation to matrimonial property, since:

"[t]he nature of the relationship between spouses and cohabitants differs from that between parties acting at arms length because it is of the very nature of such spousal and quasi-spousal relationships that the parties, while the relationship subsists, more frequently than not do not focus on the consequences of their actions." 28

The informality with which partners to a domestic relationship tend to arrange their affairs ${ }^{29}$ was posited as a factor in support of developing

23 Such factors may, however, influence the extent of any equitable interest, once the claim has been established; see Midland Bank v Cooke [1995]4 All ER 562.

24 In McFarlane v McFarlane, op cit, the court recognised that: “. . . there can be no doubt that the wife, by keeping down the household expenses, and even more, by the services she rendered in connection with the insurance broking business, had made a substantial, if indirect, contribution to the balances out of which the two properties were purchased."; ibid, at 65. Nevertheless, without an express agreement, arrangement or understanding, these indirect contributions did not support the acquisition of a beneficial interest in the property.

25 This has led the courts, in some circumstances, to infer 'agreement' from somewhat tenuous facts, see Eves v Eves [1975]1 WLR 1338; Grant v Edwards [1986]Ch 638. In Lloyd's Bank plc v Rosset, Lord Bridge commented that: "Spouses living in amity will not normally think it necessary to formulate or define their respective interests in property in any precise way. The expectation of parties to every happy marriage is that they will share the practical benefits of occupying the matrimonial home whoever owns it. But this is something quite distinct from sharing the beneficial interest in the property asset which the matrimonial home represents"; [1990]1 All ER 1111 at 1115.

26 Discussion Paper, para 6.15.

27 Ibid.

28 Ibid.

29 "It is a reality of life that parties normally enter into marriage or cohabitation relationship without any precise appreciation of the legal consequences of the relationship or on their property rights and this continues during the subsistence of the marriage"; ibid. 
separate principles to govern the ownership of matrimonial property. ${ }^{30}$ The Committee therefore proceeded to review the options for reform.

\section{(b) The reasoning of the LRAC: Commonwealth comparisons}

The LRAC compared the present position in relation to matrimonial property law in Northern Ireland with the equitable principles which have been adopted in some other jurisdictions to govern the beneficial ownership of the family home. ${ }^{31}$ The Committee focused on the more flexible means by which proprietary interests are acquired under trusts in the Republic of Ireland, Canada, Australia and New Zealand. ${ }^{32}$ It was suggested that the slightly more flexible approach taken in Ireland, ${ }^{33}$ and the remedial constructive trust which has been developed elsewhere in the Commonwealth, ${ }^{34}$ enabled their courts to reach more satisfactory results in

30 "The difference between spousal and quasi-spousal relationships on the one hand and other ordinary commercial and social relationships on the other calls for a difference of approach in relation to determining their intentions or to ascribing presumed or deemed intentions to them"; ibid.

31 See Discussion Paper, Chapter Five.

32 The Committee did not, however, examine the New Zealand experience of statutory co-ownership. The New Zealand legislature has implemented two separate models of statutory co-ownership in connection with matrimonial property. The Joint Family Homes Acts 1950 and 1964 introduced a scheme of statutory co-ownership between spouses, with additional protections against creditors. This legislation differed from the Northern Ireland proposals, however, as the co-ownership scheme was 'opt-in' rather than 'opt-out'. Spouses were required to register their property as a joint family home in order to benefit from beneficial co-ownership and the other protections provided under the Acts. The failure of many spouses to take the positive step of registering their properties as joint family homes led to the introduction of an alternative scheme, in the Matrimonial Property Act 1976. Under the 1976 Act, the beneficial interest of all matrimonial properties (ie, that of spouses) whether registered or not, is jointly owned. A significant difference between this scheme, and that proposed in Northern Ireland, however, is that co-ownership under the New Zealand Matrimonial Property Act does not crystallise until the partners separate or one partner dies. Acquisition of a proprietary interest is delayed until the court makes an order recognising the parties' joint interests. In this respect it is a 'remedial' form of statutory co-ownership. The New Zealand legislature is currently debating proposals to extend the automatic operation of the MPA to cohabitants and samesex partners, by virtue of the De Facto Relationships (Property) Bill. It is suggested that the MPA 1976 will subsequently be known as the Relationships (Property) Act. See further, Fisher on Matrimonial Property (2 ${ }^{\text {nd }}$ ed, 1984, Wellington: Butterworth New Zealand) and looseleaf version. The LRAC did acknowledge that: "[s]everal state legislatures in Canada have moved from the traditional principle of the separation of property to a variety of systems involving some aspect of community of property"; Discussion Paper, para 5.4, but these systems were not considered by the Committee.

33 The Discussion Paper noted that: "After $M c C$ v $M c C$ ([1986] ILRM 1) it appears that indirect contributions will give rise to an equity without agreement and it has been held that non-financial contributions to a husband's business. . . or managing a block of rented flats. . . will give rise to an equity"; ibid, para 5.2.

34 The Discussion Paper referred, inter alia, to Pettkus v Becker [1980]2 SCR 834; [1980] 117 DLR (3d) 257. Sorochan v Sorochan [1986]2 SCR 36 and Peter v Beblow [1993]1 SCR 980 (Canada, unjust enrichment, see paras 5.4-5.10); Baumgartner v Baumgartner [1987]164 CLR 137; Millar v Sutherland 
disputes involving the ownership of matrimonial property than the principles which currently govern the acquisition of interests in Northern Ireland. There are, however, some important distinctions to be made between the proposals put forward by the Committee for reform of the law in Northern Ireland, and the remedial constructive trust developed in the Commonwealth jurisdictions, and referred to in the Discussion Paper.

First, the Commonwealth approaches, whereby a non-owning partner can acquire an equitable interest in property under a constructive trust when the legal title holder has either acted unconscionably, or has been unjustly enriched at the expense of the non-legal title holder, generally involve some element of fault on the part of the legal title holder, and detriment suffered by the non-owning partner. The Commonwealth courts have taken account of indirect and/or labour contributions when assessing detriment. Nevertheless, a constructive trust will not arise unless certain criteria are met. ${ }^{35}$ In the Commonwealth jurisprudence considered by the LRAC, there has remained some element of quid pro quo between the parties. Although criticisms of the Northern Ireland ${ }^{36}$ approach have tended to focus on the lack of consideration given to indirect and labour contributions, ${ }^{37}$ the Northern Ireland proposals have sidestepped the issue of contributions - direct, indirect or labour - altogether. Whilst in the Commonwealth examples cited it remains necessary for individual spouses or cohabitants to establish an interest under a constructive trust on a case-by-case basis, ${ }^{38}$ the proposed reforms would confer property rights ${ }^{39}$ on qualifying partners on the basis only of their relationship with the legal title holder. The LRAC has suggested that a joint beneficial interest should accrue to the non-owning spouse (or qualifying cohabitant), regardless of whether or not any contribution, direct, indirect or non-financial, is made by the non-owning

[1991]DFC 95; Hibbertson v George [1989]DFC 95064 (Australia, unconscionability, see paras 5.11-5.14); Hayward v Giordani [1983]NZLR 140; Gillies v Keogh [1989]2 NZLR 327 (New Zealand, unjust enrichment, see paras 5.15-5.16).

35 In Canada, and to some extent New Zealand, the courts have developed the constructive trust on the basis of 'unjust enrichment': “. . . an enrichment, a corresponding deprivation and absence of any juristic reason for the enrichment"; Pettkus v Becker (1980)117 DLR (3d) 257 at 274, see also Gillies v Keogh [1989]2 NZLR 327, where the court also referred to 'reasonable expectations'. In Australia, the focal point has been 'unconscionability': “. . . equity will not permit the other party to assert or retain the benefit of the relevant property to the extent that it would be unconscionable for him to do so"; Muchinski v Dodds [1985]160 CLR 583

36 And of the similar position in England and Wales, since the House of Lords followed the decision of the Northern Ireland Court of Appeal in McFarlane $\mathrm{v}$ McFarlane [1972]NI 59 in Lloyd's Bank v Rosset [1991]1 AC 107.

37 See, for example: "Acquiring an interest in another's property", Dixon, [1991] Cambridge LJ 38-40; "A woman's work. . . ", Gardner, [1991] MLR 126-129; "Lloyd's Bank Plc v Rosset - McFarlane v McFarlane revisited"; O'Hagan, [1991] NILQ 238-245; "The home: excuses and contributions (Parts 1\&2)" (1995) 145 NLJ 6688 pp 423 et seq; (1995) 145 NLJ 6689 pp 456 et seq.

38 Albeit under more flexible equitable principles than those which have been applied in the Northern Ireland courts.

39 In the absence of contrary agreement recorded in writing. 
spouse or cohabitant. The basis of the proposed reforms is the relationship between the partners, rather than the conduct of one or both of them.

Another distinguishing factor rests with the remedial nature of the Commonwealth constructive trust. As a remedial rather than a substantive device, any trust arising under these principles does not take effect until the court declares its existence. The interest of a beneficiary under such trust does not therefore crystallise until the court recognises his or her claim. This is of particular importance in relation to dealings with third parties which have taken place prior to the litigation and which, under the remedial constructive trust, are not affected by the non-owning partner's claim. The Northern Ireland proposals, on the other hand, would involve the conferral of substantive property rights on spouses and qualifying cohabitants, which could affect the priority of third parties, thereby requiring them to investigate the possibility of such claims prior to engaging in any dealings involving matrimonial property. ${ }^{40}$ In this respect, therefore, the Northern Ireland proposals would have a substantially different effect with regard to dealings with third parties in comparison with the Commonwealth examples considered in the Discussion Paper.

\section{(c) The reasoning of the LRAC: the proposed solution for Northern Ireland}

The proposals of the LRAC are based on the recommendations of the English Law Commission in its 1988 report, 'Family Law: Matrimonial Property'. ${ }^{41}$ The Northern Ireland proposals, however, go much further than the Law Commission's 1988 recommendations, ${ }^{42}$ which were confined to ownership of household goods, ${ }^{43}$ and which applied only between spouses.

40 Under the usual provisions, that is: Land Registration Act (NI) 1970, Schedule 5, para 15 for registered land; 'reasonable inspections and inquiries' for unregistered land. See below, section 4 (a).

41 Law Com No 175 (1988). The Law Commission's 1988 proposals were in turn based on an earlier report, 'Third Report on Family Property: the Matrimonial Home (Co-ownership and Occupation Rights) and Household Goods, Law Com No 86 (1978). See further below, section 3(a). The English Law Commission has approached issues of family property from a proprietary perspective since its first Working Paper and Report on Family Property, A New Approach, Law Com WP No 42 (1971) and Law Com No 52 (1973).

42 That is, that: “. . . in future the purchase of property (with some exclusions) by one or both spouses for their joint use or benefit should give rise to joint ownership of that property subject to a contrary intention on the part of the purchasing spouse, known to the other spouse [and]. . . that the transfer of property by one spouse to the other for their joint use or benefit should give rise to joint ownership of that property subject to a contrary intention on the part of the transferring spouse, known to the other spouse."; Law Com No 175 (1988), para 5.1, 5.2.

43 See Law Com No 175 (1988). The policy of the Law Commission in excluding real property was acknowledged by the LRAC, Discussion Paper, para 6.20, although the LRAC stated that it was: “. . . presently not convinced that these are compelling reasons to justify treating the joint residence differently from other property which would be covered by the recommended changes in the law which we provisionally propose in respect of personal property"; para 6.21. The exclusion of the family home by the English Law Commission in 1988 is considered further below, see section 3(a). 
The inclusion of cohabitants is one of the more radical aspects of the Northern Ireland Report. Where property is transferred between cohabitants, or purchased by both or by one cohabitant, the beneficial interest will be vested in both partners as joint tenants unless they expressly agree otherwise in writing. The introduction of these recommendations would reverse the current position, whereby a cohabitant (or spouse) cannot acquire a proprietary interest in property without 'opting-in' to co-ownership either expressly ${ }^{44}$ or impliedly. ${ }^{45}$ The proposals set out in the LRAC's Final Report would operate conversely, so that where property was acquired or transferred by one (or both) qualifying partner(s), both partners would become beneficial joint tenants unless they expressly agreed to the contrary.

The proposals, which operate to introduce joint beneficial ownership where A transfers property to $\mathrm{B}$, or to $\mathrm{A}$ and $\mathrm{B}$, would also remove the common law presumption of advancement when property is transferred from husband to wife. ${ }^{46}$ The Committee described the presumption as outdated, ${ }^{47}$ particularly with regard to its gender bias. ${ }^{48}$ Furthermore, the Final Report recognised the potential difficulties presented by the presumption of advancement in respect of Article 5 of Protocol 7 of the European Convention on Human Rights. ${ }^{49}$ The Committee considered whether to abolish the presumption, or to provide an equivalent presumption in favour of husbands, concluding that:

"In the light of our proposed recommendations which deal with many aspects of matrimonial property but exclude other assets such as business assets or secondary residence we consider that there no longer remains any pressing need to retain any presumption of advancement." 50

The policy of the LRAC's proposals is, in this respect, very much in line with current thinking regarding the presumption of advancement. Although the presumption continues to apply in England and Wales, the English Law Commission recommended its abolition in $1988,{ }^{51}$ and the presumption has

44 By taking joint legal title over the property, or expressly creating an interest under a trust.

45 By agreeing, arranging or understanding that the ownership of the property is to be shared, or by direct financial contribution.

46 Final Report, para 5.38.

47 "The presumption of advancement is itself nowadays a somewhat fictional implication as indeed is a presumption of a resulting trust which contradicts the apparent legal title"; Discussion Paper, para 6.17.

48 The Discussion Paper noted that: " $[t]$ his presumption of advancement, which still applies, has been criticised as being an outdated inference of a fact which 'an earlier generation of judges drew as to the most likely intentions of earlier generations of spouses belonging to the propertied classes of a different social era'”; para, 3.19; quoting Lord Diplock in Pettitt v Pettitt [1970]AC 777.

49 Article 5 of Protocol No 7 provides (inter alia) that: "Spouses shall enjoy equality of rights and responsibilities of a private law character between them, and in their relations with their children, as to marriage, during marriage, and in the event of its dissolution." Although Protocol 7 has not yet been ratified, the Committee noted that since: ". . . the United Kingdom appears to wish to ratify the protocol any new law should comply with the protocol”; Final Report, para 5.38.

50 Final Report, para 5.38.

51 "We proposed in the working paper [Transfer of Money between Spouses, (1985), Law Com WP No 90] and our proposal was generally liked, that the presumption 
been statutorily removed in both Australia and New Zealand. ${ }^{52}$

The decision to include 'qualifying cohabitants' ${ }^{53}$ within the scope of the reform initiative was based upon the Committee's prediction that although: ". . . cohabiting relationships are not as common in Northern Ireland as in England and Wales and the vast majority of couples living together do so in a formal spousal relationship."; 54 the increase in cohabiting relationships in other European Union states supported an inference that: " $[\mathrm{t}]$ he number of such relationships in Northern Ireland is likely to grow (with the consequence that that will have in relation to property disputes)." ${ }^{55}$ The Committee, in formulating its policy towards cohabitants, considered the social arguments against extending the protections proposed for spouses to cohabitants, that is, that:

“. . . by applying those protections and drawing those inferences, society would or might be perceived as equating the cohabitation relationship with marriage, thereby further weakening the stable family unit which draws it (sic) full strength only from the married state. Society, it would be argued, would be placing cohabitation on the same moral and functional plane as marriage." 56

The LRAC assumed that 'qualifying cohabitants' could be regarded as: “. . . living in a committed and stable relationship to the extent of sharing their lives and pooling their financial, emotional and physical resources in the

of advancement should apply to both spouses. The detailed recommendation amounts to something slightly different from a straightforward extension of the presumption of advancement. If one spouse transfers money or property to the other not for joint purposes, it is to be presumed that a gift is intended, in the absence of evidence to the contrary. This change will remove a discriminatory aspect of the law, and do so in such a way as to reflect what is believed to be the wishes of most married couples. It will not force a spouse to make a gift. The transferring spouse can bring evidence. . to show that he or she intended to retain ownership and that the receiving spouse was to be a trustee or an agent and that the receiving spouse knew of this. ... We suspect that this recommendation will make relatively little change in practice, as the evidence at present required to prove a gift where property is transferred from wife to husband is not very great, but will avoid doubt and make the law more certain"; Law Com No 175 (1988), para 4.19.

52 The common law presumption of advancement between husband and wife was abolished in New Zealand in 1976, see Matrimonial Property Act 1976, section 4(2). The Married Person's Property Act 1986, section 9 was of similar effect in Australia.

53 See generally, Final Report, Chapter 4.

${ }_{55}$ Final Report, para 4.5, see also Discussion Paper, para 4.5.

$55 \mathrm{Ibid}$."There are a number of reasons why such relationships are likely to continue to increase. The fall-off in religious observance, a less religious view of matrimony, the increase in divorces and separations, the changes that have occurred in respect of the permanence of marriage and the marriage commitment, the perceived lack of any great financial or fiscal advantage in marriage as opposed to cohabitation, the increase in the number of economically active women and the changes in the pattern of child-bearing have (inter alia) contributed to an increase in the number of such quasi-spousal cohabitation relationships. These factors will apply in Northern Ireland as elsewhere in the United Kingdom"; ibid.

56 Final Report, para 4.9. 
common venture of living together as a unit. . ."; 57 and that consequently, it was: “. . . difficult to justify treating their property rights and interests differently from spouses." $" 58$

The LRAC suggested that the introduction of its proposals would: “. . . approximate more closely to the intention of the parties who, according to the statistics, when they actually consider the question of title to the matrimonial home, normally decide to have it vested in joint names." 59 Although the committee does not state the source of these 'statistics', the research on which this proposition is based may be that referred to earlier in the Discussion Paper ${ }^{60}$ presumably the survey carried out by $\mathrm{J}$ E Todd on behalf of the English Law Commission in 1972.61 If this is the case, it is significant to note that the findings of that study were based upon the opinions of surveyed spouses, and that the views of cohabitants were not canvassed. The Discussion Paper presumed that similar outlooks would prevail amongst unmarried cohabitants, and that such partners would be likely to perceive and organise their relationships in the same manner as spouses. ${ }^{62}$ It was therefore concluded that: "If the existing law produces potentially unfair and unreal results so far as married couples and particularly wives are concerned, then the results so far as cohabitants are concerned are likely to be equally unfair and unreal." ${ }^{63}$ It is interesting to note, however, that proposals in New Zealand to extend statutory co-ownership under the Matrimonial Property Act $1976^{64}$ to cohabitants and same-sex couples have prompted a dramatic increase in 'pre-nuptial' pacts. ${ }^{65}$ It has been reported that while: “. . . the majority seem to be glad their relationships are getting some recognition at last. . . they do not see why Parliament should interfere with their lives." ${ }^{\circ 6}$ One practitioner was quoted as reporting that property sharing pacts had trebled in the preceding three-month period. Another added that: "De facto couples are definitely concerned. They want to defend

57 Final Report, para 4.10.

58 Ibid.

59 Discussion Paper, para 6.23.

60 "As long ago as 1972 research found. .."; Discussion Paper, para 6.1.

61 Matrimonial Property (1972, London: HMSO).

62 "Their intentions are likely to be the same and the organisation of their financial affairs will be unlikely to differ to any material degree"; Discussion Paper, para 4.10, also Final Report, para 4.10.

63 Discussion Paper, para 4.10. "The extension to cohabitants of the protection and inferences which we provisionally recommend in respect of spouses is not intended to represent a moral judgment on the status of cohabitation as compared to marriage. In reality our provisional recommendations would represent an enhancement of the position of women in relationships. It would be hard to justify the strengthening of the position of women in marriage relationships and leave untouched the position of women in unmarried relationships who are already in a weaker more vulnerable position than wives, in view of the absence of the presumption of advancement and in view of the lack of availability of any appropriate adjustment powers which the Court may exercise in a divorce context"; ibid, para 4.11, Final Report, para 4.13.

${ }^{64}$ See above, footnote 32.

65 Without the nuptials!

66 Anne Beston, New Zealand Herald, 7/10/00, available on-line at: www.nzherald.co.nz. 
their property interests." ${ }^{97}$ Such anecdotal evidence provides a pertinent reminder of the property owner's perspective. The proposals for reform in Northern Ireland would not be 'automatic', but triggered by a conveyance, at which time the partners may agree in writing to opt-out. Nevertheless, the onus would be placed on a property owner who wished to retain sole legal and beneficial ownership - and in the context of, for example, a cohabiting relationship of two years, where the partners have not chosen to marry, this certainly seems to be a plausible sentiment - to take the positive step of opting-out, with all the possible adverse implications which this might have on the relationship.

When addressing the issues surrounding the inclusion of cohabitants within the Recommendations, the Final Report also considered the impact of the European Convention on Human Rights, ${ }^{68}$ particularly Article 8, which protects, inter alia, 'family life', and Article 14, which prohibits discrimination. ${ }^{69}$ The Report asserted that: "Unmarried cohabitants have a family life for the purposes of Article 8." 70 Although it was acknowledged that: "[h]eretofore arguments that they are discriminated against in areas of the law other than the law relating to children have not found much favour in the Strasbourg jurisprudence."; ${ }^{71}$ the Committee emphasised that: "[t]he Convention. . . is a living document and as societal norms change distinctions between the rights and expectations of spouses and quasi spouses may become more difficult to justify." 72 The Final Report referred also to section 75 of the Northern Ireland Act 1998, which the Committee described as: ". . . requir[ing] equality of opportunity between spouses and parties irrespective of their marital status." 73 It was suggested that:

"Consideration of any law reform proposal which impacts on either married or cohabiting couples should include consideration whether the proposal would discriminate against either and if so whether this discrimination is justified." 74

It is noteworthy, however, that while the Recommendations clearly refer to qualifying cohabitants as persons living 'as husband and wife', nowhere in the Final Report, or in the Discussion Paper which preceded it, does the Committee address the question of same-sex cohabitants, nor give any reason

67 Ibid. The effect of the New Zealand legislation would however be automatic, in the sense that the Irish proposals would have been, see footnotes 136-138 and associated text. The Northern Ireland proposals would not be 'automatic' in this strict sense; see further, below.

68 Substantially given effect in Northern Ireland by the Human Rights Act 1998, see further, below, section 4(b).

69 Article 14 provides that: "The enjoyment of the rights and freedoms set forth in this Convention shall be secured without discrimination on any ground such as sex, race, colour, language, religion, political or other opinion, national or social origin, association with a national minority, property, birth or other status."

70 Final Report, para 4.11.

71 Ibid.

72 Ibid.

73 Final Report, para 4.11.

74 Ibid. 
for their exclusion from its proposals. ${ }^{75}$ This is particularly pertinent, since section 75 of the Northern Ireland Act 1998 actually places a statutory duty on public authorities when carrying out their functions to: “. . . have due regard to the need to promote equality of opportunity [inter alios] . . . between persons of different. . . marital status or sexual orientation. . ."776.

Another question concerned the definition of 'qualifying cohabitants'. The Committee acknowledged that the broad category of cohabiting relationships encompasses a vast array of arrangements, from the most casual, to those which appear to emulate the marriage relationship. ${ }^{77}$ The statutory definition of qualifying cohabitants was, therefore, essentially a 'matter of judgment'. It was suggested, however, that the minimum threshold ought to involve 'a stable relationship with a degree of permanence. ${ }^{78}$ The Committee recommended that 'qualifying cohabitants' must either:

“(a) have lived together for a continuous period of at least two years ${ }^{79}$ within a period of the last three years in the same household; or

(b) have lived together in the same household and have had a child of the relationship." ${ }^{\circ 0}$

75 The approach taken by the Committee, as defined in the Preface to the Final Report, was confined to heterosexual relationships. Furthermore, the Committee clearly anticipated itself as providing protection for the vulnerable woman in such relationships: "Married couples are not the only vulnerable people. Couples who set up home together frequently do so usually without providing financial protection for the woman who more often than not looks after the children and the home. In the event of the home being in the sole name of the man, the woman will be in the same position as the married woman in regards of providing a right in the home and is therefore subject to the same risks from third parties as the married woman. However, in addition to these difficulties, in the event of that relationship of cohabitation breaking down, the woman has none of the protection of the 1978 Order"; Preface, pp(ii)-(iii).

76 Northern Ireland Act 1998, section 75(1)(a).

77 "Relationships of cohabitation do not conform to an identical pattern. At one end of the spectrum is the case of a couple who live together effectively as husband and wife in a joint family home with a child or children. At the other end may be the case of a couple sharing a sexual relationship, perhaps sharing a base from which to conduct that relationship but primarily leading separate lives, possibly with spouses and children of their own"; Final Report, para 4.6. "In the case of the former example it would seem likely nowadays that society would regard such a committed relationship as equivalent, or at least very close, to a state of marriage. In the case of the latter example society would still consider such a relationship as irregular and that neither party needs or merits any special legal protection so far as their property rights are concerned", ibid, para 4.7.

78 Discussion Paper, para 4.13.

79 The period of two years appears to have been based on the provisions of the Inheritance (Provisions for Family and Dependants) (Northern Ireland) Order 1996, whereby a cohabitant can be recognised as a dependant for the purposes of family provision on the basis of two years cohabitation; see Discussion Paper, para 4.2. The Final Report also referred to the provisions of various Australian states where legislation has been enacted to protect the interests of cohabitants, and where the qualifying period is between two and three years; see Final Report, para 4.15 . 
Although it is arguable that partners who have had a child together are already bound up in joint financial responsibilities, a filter mechanism based on the time scale of the relationship alone appears to be a clumsy method by which to distinguish between those relationships where the parties are likely to intend that their proprietary interests be treated with mutuality, and those in which cohabiting partners might prefer to retain financial independence. The two-year qualification suggested by the LRAC takes no account of the nature of individual cohabiting relationships which, as the Committee has acknowledged, can vary from the quasi-spousal to much more casual relationships. The definition of 'qualifying cohabitants' clearly values certainty over subtlety. The proposals as they stand would, however, have the advantage of enabling both partners and practitioners to predict accurately the operation of the provisions. In contrast to this, a qualification based on the actual relationship between two individuals would require the court to make a value judgment at the litigation stage, and would introduce further issues regarding dealings with third parties. ${ }^{81}$

The Committee also makes recommendations in its Final Report in respect of situations involving spouses and cohabitants, which fall outside the qualifying criteria. ${ }^{82}$ The Committee considered within this category, existing property relationships between qualifying partners, ${ }^{83}$ situations where the parties agree to opt-out of statutory co-ownership, but one partner subsequently makes direct or indirect contributions, and cohabitants who do not yet qualify as partners to a 'presumed stable relationship'. In respect of such parties, the Final Report proposed that: “. . . the court should have greater flexibility in determining whether and to what extent a party has an equitable claim to a beneficial interest in the joint residence." ${ }^{84}$ The Report listed a number of factors ${ }^{85}$ to be taken into account by the court, concluding that:

80 Discussion Paper, para 4.13. It was also noted in the Final Report, that the Australian states had no required time period where the cohabitants had a child of the relationship. The Committee clearly excluded same-sex relationships: "We are. . of the view that our provisional recommendations should apply to cohabitants who are living in a quasi-spousal relationship, that is to say in a relationship in which a man and woman live together as if they are husband and wife though without having married"; ibid, para 4.12.

81 The issues which ex post facto recognition of a qualifying relationship would have raised are similar to those which have been raised in comparisons between substantive and remedial constructive trusts; see section 2(b), above.

82 See Final Report, paras 5.26 et seq.

83 Since the proposed reforms are not to operate retrospectively, see further, below.

84 Final Report, para 5.34.

85 The contribution in money and money's worth, direct and indirect, made by the parties towards the cost of acquiring, maintaining, repairing and improving the premises; the contribution in money or money's worth, direct and indirect, made by the parties towards the costs of discharging any debt secured on the premises; any agreement, understanding or arrangement, express or implied, made by the parties in respect of their beneficial interest in the premises whether prior to the acquisition of the premises or during the parties' occupation of them or which they might reasonably be expected to have been made in the circumstances if they had considered the question of beneficial ownership; the degree of economic integration of the parties; the degree of permanence of the relationship between the parties (in the case of parties who are not married); the reasonable expectations of 
"... the factors which the court would take into account are closely akin to the matters which the courts take into account in Canada and Australia which apply the principles of unjust enrichment and unconscionability." 86

The Committee added that: "The Canadian and Australian experiences do not appear to suggest that our recommendation would be either unworkable or create undesirable litigation." 87 The Committee did not, however, appear to make much of the distinction between the remedial constructive trust which arises under the Commonwealth doctrines at the date of the court's judgment, and the substantive trust which would come into effect in Northern Ireland, with the capacity to bind the interests of third parties. ${ }^{88}$

Although the Northern Ireland reform initiative has tended to focus primarily on the issue of shared ownership between partners themselves, rather than the implications of the proposed statutory co-ownership on dealings with third parties involving matrimonial property, the impact of the reforms must be assessed from both viewpoints, not least because any provision which has an adverse affect on the interests of third parties may inhibit dealings with matrimonial property to the disadvantage of the partners themselves. Before proceeding to address these implications from a Northern Ireland perspective, it is useful, however, to consider some of the issues which have been raised, and which have proved problematic when statutory coownership of matrimonial property has been mooted in other jurisdictions.

\section{PROPOSALS FOR STATUTORY CO-OWNERSHIP IN OTHER JURISDICTIONS}

Although the Discussion Paper considered the equitable principles developed in some Commonwealth jurisdictions, ${ }^{89}$ the report does not refer to or assess the fate of similar proposals for statutory co-ownership in other jurisdictions, ${ }^{90}$ nor does it evaluate the difficulties which have characterised attempts to introduce such a principle in respect of matrimonial property in England and Wales, and in Ireland. The Irish Parliament and the Westminster legislature have both considered, but failed to enact, proposals which would have introduced statutory co-ownership between spouses. Although the measures attracted substantial support in the legislatures of both jurisdictions, in both cases issues arose which rendered the policies either 'too controversial' or unconstitutional. In the light of the proposals

the parties in all the circumstances of the case; any benefit accruing to the party with the legal title from other contributions in money or money's worth, direct or indirect, made by the other party; any representations, express or implied, made by either party to the other relating to the title or beneficial ownership of the premises before the acquisition of the premises or during the occupation of them; see Final Report, para 5.34.

86 Final Report, para 5.35.

87 Ibid.

88 See section 2(b), above.

89 See Discussion Paper, Chapter Five.

90 Although the Committee stated that: "Several state legislatures in Canada have moved from the traditional principle of the separation of property to a variety of systems involving some aspect of community of property"; see Discussion Paper, para 5.4; the mechanics of these systems were not discussed. 
which are currently under discussion in Northern Ireland, it is useful to consider the reasons for the failure of these policy initiatives.

\section{(a) England and Wales: the Matrimonial Homes (Co- ownership) Bill 1980}

In England and Wales, the Law Commission has, on a number of occasions, considered the introduction of statutory co-ownership between spouses as a solution to the difficulties presented by family property..$^{91}$ In its 1973 report, the Commission stated the 'main case for reform' to be that:

“. . . any law determining ownership on the basis of financial contribution necessarily applies inequitably between husband and wife, because their different roles in marriage do not give them equal opportunities to make financial contributions to the acquisition of the home. It is said that it is unfair and unrealistic to concentrate on financial contribution and to take no account of a spouse's efforts in caring for the home and family." 92

This was described as a 'more serious objection' than the arguments which had been raised in relation to the 'technicalities and uncertainties' of the present law. The Law Commission's recommendations in relation to statutory co-ownership ${ }^{93}$ were re-iterated in its 1978 report, ${ }^{94}$ and finally presented to Parliament in the Matrimonial Homes (Co-ownership) Bill 1980. Although the House of Lords appeared to embrace the policy of statutory co-ownership, the Bill was withdrawn following the decision in Williams \& Glyn's Bank Limited $\mathrm{v}$ Boland.95 The subsequent recommendations of the Law Commission in 1988, referred to in the Northern Ireland Discussion Paper, ${ }^{96}$ took a somewhat narrower approach, and did not extend the principle of co-ownership of matrimonial property to land. Whilst the Law Commission has subsequently indicated that the principle of statutory co-ownership between spouses remains a preferred policy alternative, the Government has not attempted to re-introduce a measure giving effect to this position.

It is pertinent to consider, first, the policy behind the (more extensive) proposals which formed the basis of the Matrimonial Homes (Co-ownership) Bill 1980. The Law Commission's Bill, introduced by Lord Simon in the House of Lords in 1980, ${ }^{97}$ provided that husband and wife would become statutory co-owners of land owned by either of them, which they occupied as a matrimonial home. ${ }^{98}$ It was clear that the Law Commission was influenced

91 Law Com WP No 42 (1971), Law Com No 52 (1973), Law Com No 86 (1978), Law Com No 175 (1988).

92 Law Com No 52, para 14

93 ". . . . that the interest in a matrimonial home should by law be shared equally between husband and wife unless they agree to the contrary"; Law Com No 52, para 20.

94 Law Com No 86.

95 [1981]AC 487.

96 See also Final Report, Chapter Five.

97404 HL Deb (5 $5^{\text {th }}$ Series) col 282 (17 January 1980).

98 Clause 6 provided that where husband and wife become statutory co-owners:- 
by the importance which, it was argued, ought to be attached to the matrimonial home. ${ }^{99}$ The rationale of the proposed co-ownership was derived:

“. . . not from any financial contribution, nor from any contribution to the interests of the family, nor from any other factors to be assessed by the court, but from the marriage relationship itself." 100

As with the Northern Ireland proposals, the basis of the property interest to be acquired by the non-owning partner was his or her relationship with the legal title-holder. ${ }^{101}$ The Law Commission reasoned, as did the LRAC, that the matrimonial home is: ". . . a unique item of property, and one to which a unique law of co-ownership should apply."102

Although the provisions of the Bill were well received in the House of Lords $^{103}$ on the basis that they would:

". . . not only amount to an advance in the rights of marital partners and in marital justice, they also actually enhance and help to cement the state of matrimony, marriage itself, and, through that, help to promote and safeguard the family and family life - one of the fundamental bastions of civilised society"; 104

the provisions of the 1980 Bill were less momentous than they would prima facie appear to be, particularly in relation to dealings with third parties. While the 1980 Bill would have introduced a scheme of statutory coownership between spouses, the acquisition of an equitable interest by a

if the interest is a legal estate, it shall become subject to a trust for them as beneficial joint tenants; and if the interest is not a legal estate, it shall vest in the two of them as beneficial joint tenants. Clause 11 gave the spouses the right to exclude property from statutory co-ownership by written agreement signed by both husband and wife; see Law Com No 86, Appendix to Book One.

99 "Not only is it becoming more common for families to buy their own homes, but in many cases the home is the only substantial asset of the family. Rapidly rising house prices have emphasised its position as the major family asset"; Law Com No 52, para 12 .

${ }^{100}$ Law Com WP No 42, para 0.28.

101 "Husband and wife each contribute to the home in their different ways - the wife's contributions are no less real because they may not be financial - and the home is essential to the well-being of the family as a whole."; Law Com No 86, para 0.9.

${ }^{102}$ Law Com No 86, para 0.9. Furthermore, as Lord Scarman would assert in the House of Lords, this protection was considered to be necessary because of the difficulties encountered by: ". . . the feckless, the inadequate, the uneducated, the ignorant, the helpless woman; one can apply all those adjectives to an absolutely darling person of great virtue who needs help and protection, if you like, against her own inexperience in the wiles of the world"; 405 HL Deb ( $5^{\text {th }}$ Series) col 130 , (12 February 1980). Although the Bill was not gender-specific, it was clearly intended to protect not only the family stake in the matrimonial home, but to bolster the protection of the vulnerable woman, who was unable to protect her own interests.

103 "I sense the feeling of the House moving strongly in favour of this Bill"; $405 \mathrm{HL}$ Deb (5 $5^{\text {th }}$ Series) col 128, (12 February 1980) Lord Scarman.

104405 HL Deb (5 ${ }^{\text {th }}$ Series) col 118, (12 February 1980) Lord Boston. 
spouse was not, in that pre-Boland era, considered to entitle such a spouse to assert any claim against third parties who dealt with the matrimonial property. In Bird v Syme-Thomson ${ }^{105}$ the court had described the occupation of a co-owning spouse as merely a 'shadow' of the legal owning spouse's occupation. This was crucial for the purposes of priority between the equitable owning spouse and third parties dealing with the property, for without judicial recognition of his or her independent occupation, the equitable co-owner could not utilise the protection of section $70(1)(\mathrm{g})$ of the Land Registration Act 1925. ${ }^{106}$

Lord Scarman indicated that where the spouses themselves opted, in the usual way, for joint legal ownership and had their property conveyed into their joint names:

". . . then both of them, husband and wife, have their names on the legal title to the home; everyone who deals with them, whether he be a purchaser or someone about to lend money on the house, will have notice under the machinery of the law that they are there."107

If the spouses were not legal joint owners, the non-owning spouse would, under the provisions of the Bill, have automatically acquired a beneficial interest. That beneficial interest would not, however, have affected the priority of third parties unless it had been registered. ${ }^{108}$ Although the Bill purported to confer rights of ownership on non-owning spouses, the primary significance of those rights would have been on divorce or death. In relation to debt, the non-owning spouse was still required to register a claim in order to over-ride the proprietary interest of the secured creditor. Third parties such as creditors would not have been adversely affected with constructive notice of the spouse's beneficial interest, but simply required to carry out standard investigations of title and perusal of the registers. No additional burden of inquiry would have been placed on creditors dealing with matrimonial property held under statutory co-ownership.

Although it was not anticipated when it was first drafted that the Matrimonial Homes (Co-ownership) Bill 1980 would have adversely affected third party purchasers, the decision of the House of Lords in Williams \& Glyn's Bank Limited $\mathrm{v}$ Boland, ${ }^{109}$ which was handed down during the course of legislative debate on the 1980 Bill, clarified the law in respect of the requirements placed on third parties when dealing with equitable co-owning spouses in occupation of matrimonial property. The court held that third parties are

\footnotetext{
105 [1979]1 WLR 440.

${ }^{106}$ Section $70(1)(\mathrm{g})$ protects against subsequent purchasers: “. . . the rights of every person in actual occupation of the land or in receipt of the rents and profits thereof, save where inquiry was made of such person and the right not disclosed." The equivalent Northern Ireland provision is to be found in Schedule 5 to the Land Registration Act (NI) 1970, para 15.

107405 HL Deb ( $5^{\text {th }}$ Series) col 129 , (12 February 1980) Lord Scarman.

108 “. . . suppose that. . . although co-ownership has occurred by operation of the law the wife's name has not come on to the property, then this Bill cunningly produces the necessary result. She can get a land charge registered if it is unregistered land and that is notice to the world of her interest"; ibid.

109 [1981]AC 487.
} 
required to investigate beneficial co-ownership between spouses. The enactment of the 1980 Bill, with its provision that the beneficial interest of a statutory co-owner would not bind third parties unless it was registered, was therefore inconsistent with the protection afforded by the House of Lords in Boland. The 1980 Bill was subsequently withdrawn by Lord Simon ${ }^{110}$ in order to facilitate a reconsideration by the Law Commission in the light of the Boland decision. ${ }^{111}$ Lord Simon added that although: ". . . there have been misgivings that a reference back to the Law Commission might be simply a manoeuvre to stifle the Bill"; 112 he had: ". . . been assured by the chairman of the Law Commission that there is no question of going back on the principle of co-ownership which has been accepted since 1973."113

The issue of statutory co-ownership of matrimonial property was not raised again until the Law Commission's 1988 report. ${ }^{114}$ The 1988 report, however, proposed statutory co-ownership between spouses in respect only of personal property. The Commission justified the exclusion of land on the basis of expediency:

"Our main reason for excluding land is that we believe that if we make a recommendation which has the effect of extending joint ownership of the matrimonial home, our basic principle will be seen to be controversial and may attract inappropriate opposition."115

Although the Law Commission was still in favour of extending the principle of statutory co-ownership to land, ${ }^{116}$ it was suggested that, following the Boland decision:

“. . . virtually all matrimonial homes are now purchased in joint names. It is also true that the spouses are more likely to receive legal advice when purchasing their home than when purchasing other property." 117

Nevertheless, the Law Commission continued to regard statutory coownership as the preferred solution to the challenges presented by matrimonial property. Although the Commission felt that: "[ $t]$ his further statutory intervention may not be needed"; 118 it was concluded, on balance, that:

110 On 6 October 1980.

111413 HL Deb ( th $^{\text {th }}$ Series) col 113 (6 October 1980) Lord Simon.

112 Ibid, col 114.

113 Ibid. Lord Simon claimed that: "As I understand it. . . the task of the Law Commission will be to see whether the machinery of the Bill needs any reconsideration in the light of the Boland case. My own view is that it can only have the slightest repercussion"; ibid.

114 Law Com No 175 (1988). The 1988 report is referred to in the Northern Ireland Discussion Paper, para 6.4-6.5, and in the context of the recommendations in the Final Report, see Chapter Five.

115 Law Com No 175, para 4.3.

116 "Nevertheless, most of us would support the extension of the principle of this Bill to land"; ibid, para 4.4.

117 Law Com No 175, para 4.4.

118 Ibid. 
"[w]hile such an extension, for the reason given above, would not have a major practical impact, it would be of assistance in cases where, despite the parties regarding the home as joint, it is in one name only." 119

The Law Commission has, however, remained silent on the subject of statutory co-ownership since 1988, and Parliament has shown no further indication that it is likely to enact the Commission's earlier recommendations.

\section{(b) Ireland: the Matrimonial Homes Bill 1993}

Whilst the English proposals for statutory co-ownership were stalled by concerns regarding the implications which equitable co-ownership between spouses would have on third parties, ${ }^{120}$ this particular issue has not presented an obstacle in respect of legislation relating to matrimonial property in the Republic of Ireland. The Family Home Protection Act 1976 imposed a requirement on all purchasers in dealings involving a 'family home' to obtain the consent of a non-transacting spouse, regardless of whether such spouse has any property interest in the home. Purchasers are therefore required to investigate the matrimonial status of the transacting party, and to locate and obtain consent from his or her spouse, in order to complete a valid title. ${ }^{121}$ This legislation clearly protects the position of non-owning spouses vis-à-vis third parties on the basis of the marriage relationship, and whether or not that spouse has any ownership interest in the property. The Irish legislature was not deflected by arguments that third parties would be required to carry out onerous investigations into the matrimonial relationships of vendors. ${ }^{122}$ The provisions of the 1976 Act did not, however, confer any substantive proprietary interest on the non-owning spouse, but merely an effective right of veto over dealings by the legal title-holder with third party creditors or purchasers. The 1976 Act, which focused on dealings with third parties, rather than ownership between the spouses, did not address the position of a non-owning spouse in circumstances of separation or death. It was these gaps in the protection of the spouse which prompted the introduction of proposals for statutory co-ownership of matrimonial property in the Matrimonial Homes Bill 1993.

The concept of statutory co-ownership between spouses had been considered in Ireland as a possible policy alternative prior to the enactment of the Family Home Protection Act 1976, and was re-considered in 1993. In debates preceding the 1976 Act, its provisions were regarded as a first step towards community of property. It was noted that the Commission on the Status of Women had:

119 Ibid.

120 Following the Boland decision.

121 Failure to comply with the provisions of the 1976 Act does not merely affect the purchaser's priority, but renders the transaction void.

122 It was suggested of creditors that: "[w]hen they put their money into bricks and mortar and tiles. . . [they] must understand that what is going to be making use of that is not just somebody else making money but a complex human organism which we recognise to be the foundation stone of society, namely, the family"; 291 Dail Eireann Debates (27 May 1976) col 369, Mr Kelly. 
“. . . recommended that a system of community of property be examined [and]. . . as a short term idea, they recommended the introduction of a system of protection against vindictive sales that would require the husband to consult with his wife before disposing of the home."123

It was apparent, however, that even when enacting the 1976 Act, the Irish Parliament considered statutory co-ownership to represent the ultimate solution to the family home question. ${ }^{124}$ In debates on the 1993 Bill, the Family Home Protection Act 1976 was described as a 'stop-gap' measure which, although giving the non-owning spouse: “. . . no interest at all. . . at least. . . gave them the right to object to the mortgaging or sale of the house." $" 125$

The Matrimonial Homes Bill 1993 purported to go beyond these provisions by conferring on spouses equal rights in the family home, ${ }^{126}$ through automatic joint beneficial ownership of the property. ${ }^{127}$ In this sense, the Matrimonial Homes Bill would have conferred a different type of protection from that provided by the Family Homes Protection Act 1976. ${ }^{128}$ Whilst:

"[t]he Family Home Protection Act was a very important measure. . . its effect was limited in a negative kind of way. It did not actually vest any ownership interest or take a proactive position in actually changing an ownership of the matrimonial home and vesting an actual property right in the wife." 129

The interests of non-owning spouses vis-à-vis third parties had been addressed in the 1976 Act, but the 1993 proposals would have altered the

123291 Dail Eireann Debates, (25 May 1976) col 74.

124 "The ideal is joint ownership of the family home. This is essential to the partnership which exists in marriage, to the dignity of both parties to the marriage, and essential to basic justice"; 291 Dail Eireann Debates, (25 May 1976) col 110, Mrs Desmond. "Every encouragement should be given to have joint ownership, because it is the easiest way of protecting the wife and of ensuring that a house will not be sold over a wife's head"; ibid, col $115, \mathrm{Mr}$ Collins.

125433 Dail Eireann Debates (7 July 1993) col 1600, Mr D Ahern. "It was badly drafted legislation and I agree with some speakers here who have said we ought to take our time with this"; ibid. Mr Ahern also indicated that neither the 1976 Act, nor the Bill under debate took account of the position of cohabitees. He added that: "I accept that it could have very significant implications for our social legislation, but as a compassionate race we should look at it. We have to accept that there are many unions which do not get the protection of legislation put through this House"; ibid, at 1600-1.

126 "The object of this Bill can be simply stated. It is to give spouses equal rights in the ownership of the matrimonial home"; 433 Dail Eireann Debates (7 July 1993) col 1552, Minister for Equality and Law Reform (Mr Taylor).

127 As with the Northern Ireland proposals, spouses could elect to opt-out of the statutory co-ownership scheme and make independent arrangements.

128 "The thrust of the Matrimonial Homes Bill has some features in common with the Family Home Protection Act but it is an advance in a different direction. It gives different protections in different kinds of situations"; 434 Dail Eireann Debates (13 October 1993) col 1046, Mr Taylor.

129 Ibid. 
ownership of the property between the spouses, thereby ensuring that the non-owning spouse would be protected in the event of death or divorce.

Although the Bill passed successfully through the Dail, the Irish President referred it to the Supreme Court to test its constitutionality. ${ }^{130}$ The Supreme Court held that, although:

“. . . the provisions of this Bill are directed to encourage the joint ownership of matrimonial homes and. . . such an objective is clearly an important element of the common good conducive to the stability of marriage and the general protection of the institution of the family. . . it is the opinion of the court that the right of a married couple to make a joint decision as to the ownership of a matrimonial home is one of the rights possessed by the family which is recognised by the State in Article 41.1.1 of the Constitution." 131

The Supreme Court held that spouses had a Constitutional right to make joint decisions in relation to their family property, and that the Bill's application of joint ownership to all married couples interfered with the right to make their own decisions in respect of family life. ${ }^{132}$ Although Finlay CJ claimed that:

"[t]he court accepts, as it has indicated, the advantages of encouraging by any appropriate means joint ownership in family homes as being conducive to the dignity, reassurance and independence of each of the spouses and to the partnership concept of marriage which is fundamental to it"; 133

it was held that this did not justify: “. . . the potentially indiscriminate alteration of what must be many joint decisions validly made within the authority of the family. . ."134 The Supreme Court therefore held that the Matrimonial Homes Bill was unconstitutional.

130 In the Matter of Article 26 of the Constitution and in the Matter of the Matrimonial Homes Bill 1993 [1994]ILRM 241, Supreme Court.

$131 \mathrm{Ibid}$, at 252-3, per Finlay CJ. Article 41.1 .1 of the Irish Constitution provides that: "The State recognises the Family as the natural primary and fundamental unit group of Society, and as a moral institution possessing inalienable and imprescriptible rights, antecedent and superior to all positive law.”; while Article 41.1.2 states that: "The State, therefore, guarantees to protect the Family in its constitution and authority, as the necessary basis of social order and as indispensable to the welfare of the Nation and the State." The significance of the home in this context is recognised in Article 41.2.1: "In particular, the State recognises that by her life within the home, woman gives to the State a support without which the common good cannot be achieved."

132 "In some instances the net effect of these legislative proposals would be automatically to cancel a joint decision freely made by both spouses as part of the authority of the family and substitute therefore a wholly different decision unless the spouses can agree to a new joint decision to confirm the earlier agreement or unless the owning spouse can succeed in obtaining a court order pursuant to section 6"; ibid, at 254, per Finlay CJ.

133 Ibid.

134 Ibid. 
There are a number of crucial distinctions to be made between the provisions of the Irish Matrimonial Homes Bill 1993, and the current proposals of the Law Reform Advisory Committee (Northern Ireland). The first, and most obvious distinction, is that while the Northern Ireland provisions extend to include 'qualifying cohabitants', ${ }^{135}$ the 1993 Bill was limited to spouses. Of more significance, however, are the mechanics of the respective systems. Whilst the Northern Ireland recommendations propose to introduce a joint tenancy between partners on the occurrence of a specified event, the Irish provisions would have introduced 'automatic' co-ownership in its true sense. Section 4 of the 1993 Bill provided that:

"Where, upon the commencement of this section, either or both of the spouses concerned is or are entitled to an interest to which this section applies in a matrimonial home, thereupon, the interest shall, subject to the provisions of this Act, vest in them as joint tenants." 136

The vesting of the property in spouses as joint tenants was to be automatic on the commencement of the Bill, and did not depend upon being triggered by a conveyance of property. ${ }^{137}$ Furthermore, the vesting of matrimonial property in spouses as joint tenants was to be of both prospective and retrospective effect. ${ }^{138}$

It was the automatic and retrospective nature of this vesting which led the Irish Supreme Court to reject the 1993 Bill as unconstitutional. The court held that it:

“. . . accept[ed]. . . the advantages of encouraging by any appropriate means joint ownership in family homes as being conducive to the dignity, reassurance and independence of each of the spouses and to the partnership concept of marriage which is fundamental to it. It [was] not, however, satisfied that the potentially indiscriminate alteration of what must be many joint decisions validly made within the authority of the family concerning the question of the ownership of the family home could reasonably be justified even by such an important aspect of the common goal." 139

135 See section 2(c), above.

136 Section 4(3) of the 1993 Bill recited a similar provision in respect of property which either or both of the spouses became entitled to after the commencement of the Bill. Section 4(4) provided that the interest vested would be an equitable interest.

137 "The provisions of the Bill do not seek to apply to particular categories of cases only, or to particular instances of the acquisition and ownership of matrimonial homes only, but rather are applied to each and every category and instance falling within the time scale provided for in the Bill with a right of defeasance (s7)"; [1994]1 ILRM 241 at 253, per Finlay CJ.

138 "The mandatory creation of joint equal interests in the family home also applies to every dwelling occupied as a family home irrespective of when it was first acquired by the married couple concerned and irrespective therefore of the time at which a freely arrived at decision between them may have been made as to the nature of the ownership and in whom it should rest"; [1994]1 ILRM 241 at 253, per Finlay CJ.

139 Ibid, at 254, per Finlay CJ. 
Although the Constitutional provisions offended by the 1993 Bill are specific to Ireland, the LRAC has indicated its awareness of a comparable issue, that is, the possible human rights implications of statutory intervention with matrimonial property law in the manner proposed. ${ }^{140}$ These issues, and other implications of the Northern Ireland proposals, are considered below.

\section{IMPLICATIONS OF STATUTORY CO-OWNERSHIP IN NORTHERN IRELAND}

The proposals of the LRAC(NI)'s Final Report would, if introduced, effect a dramatic shift in the balance of rights, both 'internally', between spouses and qualifying cohabitants themselves, and in relation to 'external' dealings with third parties involving matrimonial property. Although the Committee looked favourably on the development of equitable principles in other Commonwealth jurisdictions, the recommendations it has made take a very different approach to the perceived inadequacies of the present law in Northern Ireland. While the Westminster and Irish legislatures have considered and attempted to adopt similar policies, the introduction of a scheme of statutory co-ownership of matrimonial property in Northern Ireland would represent an unprecedented departure within the United Kingdom and Ireland. The following section therefore considers some practical implications of the Northern Ireland proposals.

\section{(a) External affairs: the implications of the proposals on dealings involving third parties}

Although the Discussion Paper ${ }^{141}$ appears to be directed primarily towards addressing the difficulties often encountered by non-owning spouses and cohabitants in the circumstances of death, divorce or relationship breakdown, the proposals would have an obvious effect on dealings with third parties involving the joint residence of spouses and qualifying cohabitants. The legislative history of the English Matrimonial Homes (Co-ownership) Bill 1980 highlights the implications of statutory co-ownership on dealings involving third parties. The withdrawal of the English proposals, which would have required a benefiting spouse to register his or her beneficial interest in order to secure priority over third parties, was prompted by the decision in Williams \& Glyn's Bank $\mathrm{v}$ Boland. ${ }^{142}$ The decision in Boland indicated that third parties dealing with matrimonial property are required to investigate the occupation of equitable co-owning spouses to the same extent as the interests of all other persons 'with an interest. . . in actual occupation'. Although the Northern Ireland proposals would not directly affect the interests of third parties, the extension of equitable co-ownership to all spouses (and, in the Northern Ireland provisions, to qualifying cohabitants) would obviously increase the number of spouses (and cohabitants) with such interests, and consequently also the number of cases in which a third party

140 See Discussion Paper, para 6.25.1.

141 And (arguably) to a lesser extent the Final Report, see para 5.36.

142 [1981] AC 487. 
would stand to lose priority to such a claim unless appropriate investigations and inquiries were made. ${ }^{143}$

Nevertheless, concerns regarding the burden of inquiry placed on third parties by these proposals are not convincing. The immediate alarm which followed the Boland decision ${ }^{144}$ has been quelled in the twenty years which have since passed, as conveyancers have learnt to live with the requirement that they make inquiries from all occupiers. ${ }^{145}$ As the law presently stands, third parties may lose priority to any person with an interest, who is in 'actual occupation' of land, ${ }^{146}$ or where the third party fails to make 'reasonable inspections and inquiries' prior to the transaction. ${ }^{147}$ It is therefore a matter of conveyancing practice that the occupation of property (including, as a result of the decision in Boland, the occupation of spouses or cohabitants) is investigated, to ensure priority over possible equitable claims. These proposals would not augment the burden of inquiry already imposed on third parties by general conveyancing principles. Although a greater proportion of spouses and cohabitants would actually acquire equitable ownership interests, those interests would continue to bind third parties only if the partner was in 'actual occupation' (registered land) or if the third party had failed to make 'reasonable inspections and inquiries' (unregistered land). ${ }^{148}$

The Committee's proposals may, however, introduce an additional difficulty in respect of third parties, particularly secured creditors, who seek to realise

143 The Northern Ireland proposals do not, as was the case in the English Matrimonial Homes (Co-ownership) Bill 1980, depend on registration by the non-owning spouse for effectiveness against third parties.

144 The decision in Boland provided the subject matter for two Law Commission Reports, 'The Implications of Williams \& Glyn's Bank Ltd v Boland' Law Com No 115 (1982), and 'Third Report on Land Registration' Law Com No 158 (1987); as well as spawning an extensive body of commentary; see for example, Beaumont, "Mortgage Fraud, Equitable Priorities and Overriding Interests" [1989] Conv 158; Bright, "Lenders and Overriding Interests" (1988)138 NLJ 685; Deech, "Williams \& Glyn's and Family Law" (1980)130 NLJ 896; Freeman, "Wives Conveyancers and Justice" (1980)43 MLR 692; Russell, "Williams \& Glyn's Bank v Boland \& Brown: The practical implications" (1981)32 NILQ 3; also Lewis (1986)136 NLJ 459; Luxton (1986)136 NLJ 771; Sparkes [1989]Conv 342.

145 Members of the House of Lords (sitting in its legislative capacity) have suggested that: ". . . conveyancers have come to terms with it. . . the world has not come to an end as a result of the decision in Boland. . "; 437 HL Deb ( $5^{\text {th }}$ Series) col 662 (15 March 1982), Lord Hailsham, LC; see also 460 HL Deb (5 ${ }^{\text {th }}$ Series) col 1270 (5 March 1985), Lord Mishcon.

146 If the property is registered.

147 If the property is unregistered, a purchaser will be bound by constructive notice of claims which could have been discovered by making reasonable inspections and inquiries. An example of the operation of this principle in the context of the matrimonial home can be found in Kingsnorth Finance Co Ltd v Tizard [1986]2 All ER 54.

148 It is arguable that the burden which this would impose would be lower than that which currently applies in the Republic of Ireland. Under the Family Home Protection Act 1976 s2(1), the interests of spouses are protected even though the non-transacting spouse may no longer be in occupation of the property, rendering him or her much more difficult to discover. 
the capital tied up in the matrimonial or quasi-matrimonial home. One of the implications considered by the Committee was the question, left open in Ulster Bank v Carter, ${ }^{149}$ as to whether the court could decline to make an order for partition of property, or sale in lieu, under the Partition Acts 1868 and 1876 in the case of an application by a spouse, or the mortgagee or chargee of a spouse. The Final Report has proposed that a provision should be included in any forthcoming legislation to the effect that:

“. . . in the case of applications brought by spouses or cohabitants or the mortgagee or chargee of spouses or cohabitants under the Partition Acts 1868 and 1876 the court should have a general power to decline to make an order at all." 150

The Committee added that:

"[I]n exercising its power the court should be directed to take into account a number of factors:

the intentions of the persons when the joint interest was created or arose;

the purposes for which the property subject to the joint interest is held;

the welfare of any minor who occupies or might reasonably be expected to occupy any land as his home;

the interests of any secured creditor of either of the joint owners;

when the application is brought by a secured creditor, whether the co-owner against whom an order is sought was a party to the security or agreed to creation and if so whether his or her consent was freely and advisedly given; and

where the application is brought by a secured creditor whether any creditor has any other reasonable means of recovering the secured debt." 151

These factors are presented in the context of justifying the court's decision to decline to order sale. Whilst it may be arguable that a partner who acquires a beneficial interest in property without making any contribution (direct, indirect, or even through labour in the home) ought not to be permitted to force the sale of that property against the wishes of the legal title holder, the inclusion of mortgagees and chargees would raise obvious and reasonable

149 High Court (NI) Unreported, 29 January 1999.

150 Final Report, para 5.36; see also Discussion Paper, para 6.26.

151 Final Report, para 5.36. The Committee claimed that this recommendation reflected developments in English land law under section 15 of the Trusts of Land and Appointment of Trustees Act 1996, and in respect of the decision in Mortgage Corporation Ltd v Shaire [2000]Fam Law 402; see Fox, "Living in a Policy State: from trust for sale to trust of land" [2000] Liverpool Law Review 59-88. It is noteworthy, however, that the comparable English provisions are not linked to any scheme of statutory co-ownership, but apply only where partners acquire legal or equitable proprietary interests by virtue of the traditional methods. 
concerns amongst creditors, and could have an adverse effect on the marketability of (quasi-) matrimonial property as a security asset. In this respect the LRAC have tended to focus on the proposed reforms as a means of achieving 'fairness' between spouses and qualifying cohabitants, without dwelling on the implications of its recommendations on the balance of interests between partners in (quasi-) matrimonial property and third parties, or on the function of the property as a capital asset.

\section{(b) Internal interests: the implications of the proposals between partners}

The introduction of the LRAC's proposals would transform the manner in which property is held by spouses and 'qualifying cohabitants', and the operation of the presumption which these proposals would introduce raises a number of social and moral issues. Although the Committee asserted that it was not seeking to make a moral judgment, ${ }^{152}$ the basis on which the law regards a partnership as being of a sufficiently permanent nature to attract protection is likely to provoke considerable debate, as are the necessary implications of defining the type of family unit brought within the proposals. Another likely bone of contention could arise from opinions regarding the balancing of family interests and property interests. Whilst some will accept the propositions asserted by the Discussion Paper and the Final Report, which appear to favour 'fairness' towards non-owning partners, others will certainly take issue with the implications of the proposals from the property owner's perspective. This section, however, focuses on some of the legal and practical challenges such a presumption might present.

First, it is important to consider some timely questions from a human rights' perspective surrounding the legitimacy of this statutory interference with both property rights and family life. The proposals, if enacted, would involve statutory interference with the property interests, and to a certain extent, with the arrangement of family affairs, of spouses and partners to cohabiting relationships of two years or more. The provisions of the European Convention on Human Rights which have been given effect in Northern Ireland law by virtue of the Human Rights Act $1998^{153}$ include Article 1 of the First Protocol, which protects the right to property, ${ }^{154}$ and

152 "The extension to cohabitants of the protection and inferences which we recommend in respect of spouses is not intended to represent a moral judgment on the status of cohabitation as compared to marriage."; Final Report, para 4.13; see also Discussion Paper, para 4.11.

153 The Human Rights Act 1998 was commenced in full on 2 October 2000, although certain provisions of the Act, sections 6(2)(c), 24(1) and 71, as well as Schedule 10 , were given effect on devolution by the Northern Ireland Act 1998, Schedule 14. See Article 1(1) of the Human Rights Act 1998, which defines the 'Convention Rights' for the purposes of the Act. Section 22(6) extends the Act to Northern Ireland.

154 "Every natural or legal person is entitled to the peaceful enjoyment of his possessions. No one shall be deprived of his possessions except in the public interest and subject to the conditions provided for by law and by the general principles of international law. The preceding provisions shall not, however, in any way impair the right of a State to enforce such laws as it deems necessary to control the use of property in accordance with the general interest or to secure the 
Article 8 of the Convention, which guarantees the protection of, inter alia, the family. ${ }^{155}$ The Northern Ireland Act 1998 provides that legislation emanating from the Northern Ireland Assembly will be invalid if it is incompatible with any of the Convention rights. ${ }^{156}$ The Assembly is obliged to ensure that any measures which it enacts are compatible with the 'Convention rights'. It would therefore be necessary for the Assembly to consider whether the proposals under discussion for the reform of matrimonial property law meet these requirements before any provisions could be enacted.

Article 1 of the First Protocol comprises three distinct rules. ${ }^{157}$ The first rule states the principle of peaceful enjoyment of property. The second rule covers deprivation of possessions, and subjects it to certain conditions. The third rule recognises that states are entitled, amongst other things, to control the use of property in accordance with the general interest, by enforcing such laws as they deem necessary for that purpose. The second rule is relevant when there has been a deprivation of possessions, in the sense of a formal taking or expropriation, ${ }^{158}$ while the third rule applies where the interference in question is intended to control the use of property. ${ }^{159}$ Where an interference does not amount to a taking, and is not intended to control the use of property, but nevertheless has the effect of interfering with the use or enjoyment of property, the first rule may be relevant. Nevertheless, even when an 'interference' has been established, it may be justified on the basis

payment of taxes or other contributions or penalties."; European Convention on Human Rights, Protocol One, Article 1.

155 "1. Everyone has the right to respect for his private and family life, his home and his correspondence. 2 . There shall be no interference by a public authority with the exercise of this right except such as is in accordance with the law and is necessary in a democratic society in the interests of national security, public safety or the economic well-being of the country, for the prevention of disorder or crime, for the protection of health or morals, or for the protection of the rights and freedoms of others."; European Convention on Human Rights, Article 8. The effect of Article 8 has been explained thus: "Interference by the State with a person's private and family life, home, or correspondence must be justified by one of the exceptions detailed in Article 8(2) and must be the minimum necessary to obtain the legitimate aims. Only these exceptions, along with the restrictions in Article 17 are allowed. Once the state has identified a legitimate objective, prescribed by law, the Court focuses on proportionality. The Court will ask whether this interference serves a "pressing social need'."; Wadham and Mountfield, Blackstone's Guide to the Human Rights Act 1998 (1999), p 92.

156 Northern Ireland Act 1998, section 6(1) provides that: "A provision is not law if it is outside the legislative competence of the Assembly"; while section 6(2)(c) lists amongst the factors bringing provisions outside the legislative competence of the Assembly, incompatibility with any of the Convention rights. Article 24 of the Northern Ireland Act 1998 adds that: "A Minister or Northern Ireland department has no power to make, confirm or approve any subordinate legislation, or to do any act, so far as the legislation or act (a) is incompatible with any of the Convention rights. ..".

157 Sporron and Lonnroth v Sweden (1982)5 EHRR 35, E Ct HR.

158 For example, compulsory purchase.

159 For example, planning controls. 
of public interest. The over-riding principle of proportionality also applies. ${ }^{160}$

A finding of interference with the 'right to peaceful enjoyment of possessions' ${ }^{161}$ under Article 1 of the First Protocol is usually made when the state interferes directly to expropriate or control the use of property. ${ }^{162}$ It has generally been accepted that: "...private law restrictions are deemed to be defining of, rather than interferences with, property/possessions." 163 It is therefore unlikely that the recommendations of the Final Report, which would affect property rights between private individuals in certain circumstances, would be considered as constituting an 'interference' with the right to property under Article 1 of the First Protocol. It is also significant that the reforms proposed in the Discussion Paper would not affect (quasi-) matrimonial property automatically on the commencement of the Act, but on a transfer of property between parties, or acquisition of property by one or both of them. Furthermore, the proposals of the LRAC would not effect a compulsory re-allocation of the ownership of the relevant property in these circumstances, since the affected parties would retain the right to opt-out of the co-ownership provisions.

In addition, it is noteworthy that even when an interference is established, a number of justifications, for example, pursuance of the public interest, may bring the alleged breach outside the remit of Article 1 of the First Protocol..$^{164}$ In James v United Kingdom ${ }^{165}$ the European Court of Human Rights held that the: ". . . . taking of property in pursuance of a policy calculated to enhance social justice within the community can properly be described as being in the public interest." ${ }^{\prime 16}$ In this respect, it is significant that:

"[s]tates have a broad margin of discretion both in deciding what are the interests of the community in any given situation, and in striking the appropriate balance. The Court will only intervene where the measures in question are manifestly unreasonable."167

Consequently, “. . f findings of violations under Article 1/1 are comparatively rare." 168 It is submitted that the proposals of the LRAC(NI) are unlikely to be considered to be 'manifestly unreasonable' within the terms of Article 1 of the First Protocol.

160 That is, there must be a reasonable degree of proportionality with the extent of any interference, and the object or purpose of that interference.

161 The expressions 'possessions' and 'property' are treated as interchangeable for the purposes of this Article.

162 See Starmer, European Human Rights Law, (1999, LAG), pp 636 et seq.

163 Starmer, op cit, p 641. See $X$ v UK (1978)14 DR 234.

164 "Measures which interfere with property rights must have a legitimate aim, and must be proportionate. They must also strike a fair balance between the rights of the individual and the general interest of the community. .."; Coppel, J, The Human Rights Act 1998: Enforcing the European Convention in the Domestic Courts (Wiley: Chichester, 1999), para 14.8.

165 (1986)8 EHRR 123.

166 Ibid, para 41; see Starmer, p 639.

167 Coppel, J, op cit, n 164 para 14.8 .

168 Ibid. 
Under Article 8(1) of the European Convention on Human Rights, every individual is guaranteed the right to respect for, inter alia, his private and family life, and his home. ${ }^{169}$ Although the proposals of LRAC(NI) in respect of (quasi-) matrimonial property may initially appear to constitute a prima facie interference with family life, on similar grounds to those raised in respect of the Irish Matrimonial Homes Bill 1993 which were held to contravene respect for the family under the Irish Constitution, ${ }^{170}$ it is important to distinguish between the Irish provisions, which applied automatically and retrospectively, and the proposals for reform in Northern Ireland. The LRAC referred in the Discussion Paper to the implications of the European Convention on Human Rights when considering whether the proposals ought to be of retrospective effect. ${ }^{171}$ If the Northern Ireland proposals were to be of retrospective effect, ${ }^{172}$ arguments could have been raised regarding interference with decisions which had already been made in respect of the home under Article 8, similar to those arguments which defeated the Irish 1993 Bill. ${ }^{173}$ The Final Report indicated, however, that the recommendations were not to apply retrospectively. ${ }^{174}$ The proposals would not therefore involve any interference with decisions which had already been made in the context of the family. Furthermore, spouses and qualifying cohabitants may, if they wish, opt-out of the co-ownership regime. The recommendations made in the Final Report do not therefore offend the rights of family members to reach their own decisions, and consequently are unlikely to be regarded as interfering with family life to a disproportionate degree.

Another important practical issue stems from the fact that the proposed statutory co-ownership would be operational at the stage of one of the specified conveyances, and qualifying partners would have an option to optout of the provisions at this stage. Since the vesting of the property in joint owners is triggered by a conveyance, it is likely that the partners, or the transacting partner at least, would have legal advice at this point. Even in the case of an acquisition by one partner, where it might be argued that the non-

169 See above, footnote 155 for text of Article 8.

170 Bunreacht na hEireann, Article 41. See footnote 131 for excerpts from Article 41. Although Article 41 is not co-extensive with Article 8 ECHR, both deal in substance with the protection of the family. Article 41 protects the Family, and particularly the contribution made by 'woman' by 'her life within the home'. Article 8 of the European Convention on Human Rights protects, inter alia, 'private and family life', and the home.

171 “. . . retrospectively depriving parties of their legal and beneficial rights and property without compensation would be a major interference with the private rights of property and may well represent a disproportionate interference which would be unlawful under the European Convention on Human Rights."; Discussion Paper, para 6.25.1.

172 A matter on which the Committee had not reached a provisional view prior to publication of the Discussion Paper, see para 6.25.1.

173 That is, that the proposals would unjustifiably alter joint decisions which had already been reached within the family.

174 Final Report, para 5.25. The Committee's reasoning in reaching this conclusion included consideration of the prospect that retrospective effect could render the proposals open to challenge on the basis of non-compliance with Article 1 of the First Protocol, by interfering with existing rights to property, rather than Article 8. 
transacting partner will not necessarily be a party to, or aware of the conveyance, it would be the transacting partner (who will usually require the services of a conveyancer) who would stand to 'lose' by the operation of the proposed provisions. The Northern Ireland proposals differ in this respect from the 'automatic' co-ownership proposed in Ireland. The mechanics of the Northern Ireland proposals have the advantage of indirectly introducing the necessity for legal advice at the point when the provisions become operative (that is, at the time of the conveyance).

Nevertheless, the mere provision of legal advice does not necessarily ensure that a written agreement to opt out, or a private agreement between partners not to opt out, is completely voluntary. It has been accepted by the courts that parties engaged in an emotional and sexual relationship are more likely than others to be vulnerable to undue influence. ${ }^{175}$ Illegitimate pressure could operate in a number of ways: either the transacting partner could be pressured, explicitly or implicitly, into completing the conveyance without objecting; ${ }^{176}$ or the non-transacting partner might be pressured or unduly influenced into agreeing to opt out of the provisions. Even where there is no direct application of pressure, it may be difficult for a purchasing partner to express a desire to retain ownership of the property which he or she has paid for at the risk of 'upsetting the apple cart', and damaging the relationship with his or her partner.

To date, the law concerning undue influence has tended to focus upon the mere provision of legal advice as a panacea to illegitimate pressure, ${ }^{177}$ although the effect of that advice may not have been to relieve the pressure exerted over the victim. ${ }^{178}$ This issue was not addressed by the LRAC, although it could arguably provoke a considerable amount of litigation. ${ }^{179}$ In

175 Although the court rejected a presumption of undue influence between spouses, it was conceded that: "... sexual and emotional ties between parties provide a ready weapon for undue influence: a wife's true wishes can easily be overborne because of her fear of destroying or damaging the wider relationship between her and her husband if she opposes his wishes"; Barclay's Bank plc v O'Brien [1994]1 AC 180 at 190 .

176 A partner may feel that it would be detrimental to the relationship to request the non-transacting partner to agree to opt out of the provisions.

177 In the context of surety transactions, the courts have tended to regard third parties as having discharged any duty of inquiry which might arise as a result of notice (actual or constructive) of undue influence so long as the surety has been advised to take independent legal advice: see TSB Bank Plc v Camfield [1995]1 All ER 951; Bank of Baroda v Shah [1988]3 All ER 24; Lloyd's Bank plc v Egremont [1990]2 FLR 351; Midland Bank v Massey [1995]1 All ER 929; Bank of Baroda v Rayeral [1995]2 FLR 376; Midland Bank plc v Serter (1994)26 HLR 612.

178 This approach has been criticised as ". . . focus[ing] on the issue of the victim's comprehension but completely ignor[ing] the primary issue of influence"; Oldham, "Neither a Borrower nor a Lender be" - the life of O'Brien' (1995) Child and Family Law Quarterly 104 at 118. See also Credit Lyonnais Bank Nederland NV v Burch [1997]1 All ER 144.

179 The Committee considered the possible operation of undue influence only at the later stage of application for sale by a secured creditor, and regarding the subsequent agreement to use the property as security, not the decision whether to opt-out of statutory co-ownership. One of the proposed factors to be considered by the court when exercising its power under the Partition Acts to refuse sale is: ". . . whether the co-owner against whom an order is sought was a party to the 
contrast, the Irish proposals considered above ${ }^{180}$ included a requirement that parties choosing to opt out of the (proposed) scheme of statutory coownership must have received legal advice. ${ }^{181}$ Furthermore, it was also provided that: ". . . in this subsection 'lawyer', in relation to advice to a spouse, does not include a lawyer who is acting on behalf of the other spouse. . ." 182 . Although it is tempting to suggest that similar provisions ought to accompany the introduction of the Northern Ireland recommendations, it is also important to bear in mind that legal advice does not necessarily solve the problem of undue influence. Whilst the Committee's proposals may, from some perspectives, herald the introduction of a fairer system in respect of property interests in the joint residence between partners, the nature of the relationship may also, in some circumstances, cause the proposals to lead to unfair results.

\section{CONCLUSIONS}

The proposals made by the LRAC for reform of the law relating to joint residences in Northern Ireland would effect a radical transformation, encouraging co-ownership of the joint residence between not only spouses, but also cohabiting partners after only two years. The proposed reforms are intended to promote a system of matrimonial property law which produces: “. . . a fair and equitable result between husbands and wives (and, we would argue, cohabitants) but also one which is fair to wives as a class." 183 Nevertheless, the presumption of beneficial co-ownership, regardless of who pays for the property, will be a matter of concern in the eyes of those who consider the issues addressed by the Discussion Paper and the Final Report from the point of view of the property owner. Although the proposed provisions allow partners to opt out by agreement in writing, this places a burden on the property owning partner to take action 'against' his or her spouse or cohabitant if he or she wishes to retain sole ownership.

If these proposals are introduced, it is arguable that a substantial proportion of this burden could fall on the solicitors who advise such individuals. Legal advisers will be required to inform spouses and qualifying cohabitants (once the solicitor has probed the extent of their relationship) of the nature of the transaction, and its consequences, and to explain the implications of the

security or agreed to its creation and if so whether his or her consent was freely and advisedly given"; Final Report, para 5.38.

180 See section 3(b).

181 "A declaration under subs (1) shall be void unless, before making it, the spouse concerned has received advice from a lawyer in relation to the declaration and its effect"; Matrimonial Homes Bill 1993, s 7(2)(a). S 7(1)(a) contained a provision by which property could be 'opted-out' if the spouse who would benefit made a declaration in writing to that effect.

182 ". . . or who is a member of a firm of lawyers which, or another member of which, is so acting or has so acted"; Matrimonial Homes Bill 1993, s 7(2)(c). It is noteworthy that this provision went somewhat beyond the existing English common law position on the subject of legal advice and undue influence, whereby the burden of 'independent legal advice' can be discharged even though the same solicitor acts for surety and principal debtor, Midland Bank $\mathrm{v}$ Massey, supra, or for all three relevant parties, surety, debtor and creditor, Midland Bank plc v Serter, supra.

183 Discussion Paper, para 6.18. 
various available alternatives: sole or joint legal title, sole or joint beneficial ownership, statutory co-ownership and the consequences of opting-out. ${ }^{184}$ Much will depend on the quality of advice given to transacting partners, and solicitors will have to be vigilant regarding the possibility of undue influence. ${ }^{185}$

There will also still be cases to be dealt with according to established (resulting and constructive) trust principles. The main proposals apply only to spouses and quasi-spouses or 'qualifying cohabitants', and even in these cases, only to their primary residence. Although there is also a second layer of proposals, these do not encompass property held by same sex couples, nor by homesharers who are not involved in a sexual relationship. The proposals also extend only to property occupied as a residence. Traditional trust principles will therefore continue to govern a significant number of cases, which fall outside the second layer of proposals (dealing with (1) nonqualifying heterosexual cohabitants, (2) agreement to legal title in one name followed by detriment which would not under the existing law give rise to an interest under a trust, and (3) property already vested). ${ }^{186}$ This would result in three different regimes governing equitable interests in real property: statutory co-ownership for qualifying partners, with a provision to opt-out, the second layer of proposals, which deal with additional specified situations, and those cases falling altogether outside the recommendations, ${ }^{187}$ which will continue to be governed by traditional trust principles.

The general policy of the Committee's proposals echoes the memorable sentiment in support of joint legal ownership expressed by Lord Scarman in 1982. His Lordship suggested that:

“. . . we should encourage young married people to go round the corner to the solicitor, or, if we could establish one, the legal clinic, to talk about the legal problems of marriage just as they go to the medical clinic to discuss the medical problems associated with what is euphemistically called family planning." 188

Although the proportion of partners opting for joint legal title has increased exponentially since then, the proposals for reform in Northern Ireland seek to ensure that those who have not taken this positive step will be encouraged to 'turn their minds' to the question of their respective interests in the joint residence. By providing that the beneficial ownership of property would be vested in both partners as joint tenants, not by action but by passive inaction, the introduction of these proposals would change the shape of matrimonial property ownership. It is also clear, however, that for those interested in protecting not only the family interest, but their individual property interests

184 See footnotes $82-88$ and associated text.

185 See Morris, "Wives are told: don't blame the bank, sue your solicitor" (1999) Feminist Legal Studies 193, for analysis of the implications of developments in undue influence in relation to surety transactions on practitioners.

186 See Final Report, para 5.34, and footnote 85, above.

187 That is, property which is not occupied as a (quasi-) matrimonial home as defined in the Report.

188437 HL Deb (5 ${ }^{\text {th }}$ Series) col 652 (15 December 1982) Lord Scarman. 
also, the conversations which they will need to have with their solicitors will become not only more significant but considerably more complex.

There can be no doubt that the issues raised by this Report will provoke debate, and arguably controversy, both within and outside of the legal professions. To a certain degree, such debate would be an end in itself, since difficulties often arise in this area due to the fact that parties involved in personal relationships may neglect to arrange their affairs, particularly in respect of the ownership of property, in any formal manner. It is also encouraging to note that the Law Reform Advisory Committee (Northern Ireland) have recommended further research and review into the law concerning cohabitation, ${ }^{189}$ and more general issues concerning coownership. ${ }^{190}$ In the meantime, if these reform proposals encourage greater awareness of the need for homesharers to 'turn their minds' to the question of property rights in the home, and consequently to make arrangements which reflect their intentions, this could only be welcomed.

189 "We consider that the time is ripe for a wider review of the law relating to cohabitants"; Final Report, para 4.12.

190 "We also consider that the time is right for a general review of the law relating to co-ownership and recommend that this item be added to the Committee's programme of law reform or the programme of law reform of any new Law Commission established to replace the Committee.”; ibid, para 5.37. 